\title{
Screening for Tolerance to Anaerobic Germination in Rice (Oryza sativa L.)
}

\author{
K. Sudeepthi*, T. Srinivas, B. N. V. S. R. Ravi Kumar, \\ D.P.B. Jyothula and S. K. Nafeez Umar
}

Department of Genetics \& Plant Breeding, Agricultural College, Bapatla, Andhra Pradesh, India

*Corresponding author

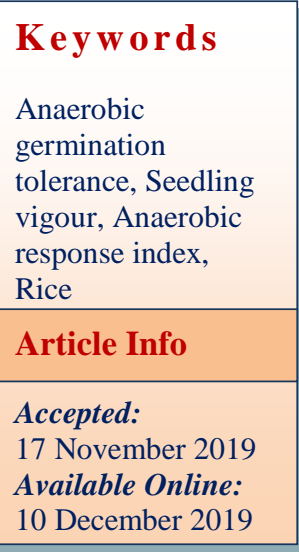

The present investigation was carried out during Kharif 2017 at Regional Agricultural Research Station, Maruteru, Andhra Pradesh with an objective to screen the rice genotypes for their tolerance to anaerobic conditions during germination and also to identify varieties suitable for direct seeded rice cultivation, using two different methods, namely, test tube method and pro-tray method. The results revealed MTU 1140 to be superior with respect to germination percent, shoot length, root length and seedling dry weight in addition to seedling vigour index and anaerobic response index in both the screening methods and hence, the genotype is identified to be most promising for growing under direct seeded conditions. Among the screening methods, test tube method of screening is inferred to be more useful for evaluating large number of genotypes, while pro-tray method of screening is recommended for greater accuracy of the results.

\section{Introduction}

Rice production in the recent years is increasingly shifting from transplanting to direct seeding, particularly under puddled conditions, due to reduction in cost of cultivation and early maturity of the direct sown crop (Pandey and Valesco, 2002). However, poor seedling establishment under direct seeding in standing water has prevented its large-scale adoption. Flooding due to rainfall or improper leveling of land, resulting in unfavorable anaerobic conditions for the rice seed, leads to poor germination and failure to develop strong and uniform seedlings under direct seeded conditions. It is attributed to the lack of tolerance to anaerobic germination (AG) which results in insufficient energy supply for the growing embryo under oxygen deficit conditions caused by 
submergence and is identified as the main limiting factor for direct seeding in rice (Yang et al., 2019). However, varietal differences for anaerobic germination were observed by Ismail et al., (2009). Further et al., (2013) reported that unique anaerobic germination processes may be more efficient in some rice genotypes. Hsu and Tung (2015) reported that genotypes tolerant to anaerobic stress exhibited rapid coleoptile elongation after germination resulting in improved seedling survival under anaerobic conditions.

Development of rice cultivars tolerant to anaerobic conditions during germination coupled with early seedling vigor was reported to be an important objective under directseeding (Joshi et al., 2013, Miro and Ismail 2013 and Vijayan et al., 2018). In this context, the present investigation was undertaken to identify rice varieties capable of surviving under flooded anaerobic conditions during germination and early growth stages for potential use under direct seeding in standing water under puddled conditions.

\section{Materials and Methods}

The experimental material consisted of 107 elite rice genotypes (Table 1). Screening of the rice varieties for their tolerance to anaerobic conditions was undertaken at Regional Agricultural Research Station, Maruteru during Kharif 2017 with test tube method detailed by Hsu and Tung (2015) and pro-tray method detailed by Chaitanya (2016). Screening of rice varieties under both methods was carried out in completely randomized design with two replications.

Screening with test tube method was undertaken with three days pre-germinated seeds at pigeon breast stage in glass test tubes (25 $\mathrm{mm}$ in diameter and $150 \mathrm{~mm}$ in height) filled with $10 \mathrm{~cm}$ deep distilled water (Plate 1). In pro-tray method, seeds were sown in pro-trays of $(35.5 \times 10 \times 4.5 \mathrm{~cm})$ at about $1 \mathrm{~cm}$ soil depth and submerged in tanks (Plate 1). Observations were recorded after seven days in the test tube method and after $14^{\text {th }}$ day of submergence in the pro-tray method. Data on number of seedlings survived after 7 or 14 days of submergence was recorded as germination percentage (\%). In addition, shoot length $(\mathrm{cm})$, root length $(\mathrm{cm})$ and seedling dry weight $(\mathrm{mg})$ were recorded for each variety in both the methods in each replication. Further, seedling vigour index (Kharb et al., 1994) and anaerobic response index (Hsu and Tung, 2015) were estimated as per the standard procedures suggested by earlier workers.

\section{Results and Discussion}

The results on screening of 107 rice genotypes for their ability to germinate under anaerobic conditions of standing water was evaluated with respect to six anaerobic germination traits, namely germination per cent, shoot length, root length, seedling dry weight, seedling vigour index and anaerobic response index and the range of results obtained are presented in Table 2 and Figure 1. Wide variability was noticed for all the traits studied with respect to response of the rice genotypes under anaerobic conditions under both methods of screening. Germination per cent in the present study ranged from 20 (MTU 1156 and RTCNP 23) to 99 per cent (MTU 1140) in the test tube method of screening and from 25 (MTU 1010, MTU 1156, BPT 3291, MTU 1187, MTU 1064 and Nonabokara) to 95 per cent (MTU 1140 and RTCNP 50) in pro-tray method. Based on germination percentage, the rice genotypes were classified as susceptible (0-50\%), moderately tolerant (51-75\%) and tolerant (76-100\%) in accordance with the classification given by Manigbas et al., (2008).

In test tube method of screening, 11 rice genotypes recorded less than 50 per cent germination and were susceptible for 
anaerobic conditions. Ten rice genotypes recorded 50-75 per cent germination and hence, were classified as moderately tolerant. However, 86 genotypes recorded more than 75 per cent germination and were classified as tolerant for germination under anaerobic conditions. In Pro-tray method of screening, 20 rice genotypes had recorded less than 50 per cent germination and were found to be susceptible for germination under anaerobic conditions, while 53 rice genotypes recorded 50-75 per cent germination and hence were classified as moderately tolerant. However, 34 genotypes recorded more than 75 per cent germination under this method and were classified as tolerant for germination under anaerobic conditions. In both the screening methods, highest germination percentage was recorded by MTU 1140 (95\%) and lowest was recorded by MTU $1156 \quad(<26 \%)$ High germination percentage of the tolerant genotype, MTU 1140 and others might be due to their rapid breakdown of starch into soluble sugars, useful for growing embryo. Girijarani et al., (2014) also reported MTU 1140 to be able to withstand anaerobic conditions during germination. The results are also in conformity with the reports of Reddy and Girijarani (2018). Further, eight genotypes were observed to be susceptible while four were moderately tolerant to germination under anaerobic conditions. However, 31 genotypes were observed to be tolerant uniformly under both methods of screening (Table 3) and may be recommended for direct seeding under standing water.

Rapid shoot growth is also considered as one of the important traits associated with anaerobic germination tolerance (Ismail et al., 2009). Highest shoot length was exhibited by MTU $1140(25.65 \mathrm{~cm})$ in pro-tray method and RTCNP $28(3.62 \mathrm{~cm})$ in test tube method, indicating their tolerance for anaerobic conditions. The tolerance may be attributed to their rapid shoot elongation when compared with susceptible genotypes so as to reach the water surface resulting in diffusion of air to the growing leaf and root for better seedling establishment. Similar results were reported by Rauf et al., (2019). In the present study also, the susceptible genotypes had recorded low shoot length. Lowest shoot length was exhibited by SM-10 $(9.75 \mathrm{~cm})$ in pro-tray method and SM-3 $(1.12 \mathrm{~cm})$ in test tube method.

Differential responses of root growth were also observed in the genotypes studied in both the screening methods. Root length was observed to range from $0 \mathrm{~cm}$ (MTU 1078, MTU 1166, MTU 1187, SM-3, SM 3-1and RTCNP 14) to $4.85 \mathrm{~cm}$ (MTU 1032) in the test tube method and from $0.35 \mathrm{~cm}$ (MTU 1010 ) to $6.65 \mathrm{~cm}$ (MTU 1140) in the pro-tray method of screening. MTU 1140, the tolerant line has exhibited maximum germination per cent $(95 \%)$ and also maximum root length $(6.65 \mathrm{~cm})$ in the pro-tray method, while minimum germination per cent $(25 \%)$ and root length $(0.35 \mathrm{~cm})$ was recorded for MTU 1010 , the susceptible line in the pro-tray method of screening, indicating the relationship of germination per cent and root length in tolerant and susceptible lines for anaerobic conditions. The results are in broad agreement with the reports of Bordoloi and Sharma (2018).

The trait, seedling dry weight also exhibited wide variation among the genotypes studied. It ranged from $14 \mathrm{mg}$ (RTCNP14) to $26 \mathrm{mg}$ (RTCNP 15, RTCNP 23, RTCNP 37 and RTCNP 39) in test tube method of screening and from $13.75 \mathrm{mg}$ (MTU 1010) to $32 \mathrm{mg}$ (MTU 1140) under pro-tray method of screening. The tolerant genotype, MTU 1140 has recorded maximum seedling dry weight of $32 \mathrm{mg}$ under pro-tray method of screening, while the susceptible genotype, MTU 1010 has recorded minimum seedling weight of $13.75 \mathrm{mg}$ under pro-tray method of screening, indicating the relationship between seedling dry weight and tolerance for anaerobic 
conditions. Similar results were reported by Barik et al., (2019).

Ample variation was also noticed among the genotypes for seedling vigour index, calculated based on germination percentage, shoot length and root length. In the test tube method, seedling vigor index ranged from 0.76 (MTU 1010) to 4.77 (MTU 1140), while in pro-tray method, it ranged from 3.65 (MTU 1010) to 27.00 (MTU 1140). Results of the present study revealed that high germination rate, rapid shoot and root elongation are major traits closely related to seedling vigour and responsible for optimum seedling establishment under submerged conditions. These results are in agreement with earlier findings of Barik et al., (2019).

Table.1 List of genotypes screened in the study for different anaerobic germination traits

\begin{tabular}{|c|c|c|c|c|c|}
\hline S.No. & Genotype & Source & S.No. & Genotype & Source \\
\hline 1 & BPT 5204 & ARS, Bapatla & 34 & MTU 5249 & RARS, Maruteru \\
\hline 2 & BPT 3291 & ARS, Bapatla & 35 & MTU 5293 & RARS, Maruteru \\
\hline 3 & BPT 2231 & ARS, Bapatla & 36 & MTU 7029 & RARS, Maruteru \\
\hline 4 & FL 478 & RARS, Maruteru & 37 & NONABOKRA & RARS, Maruteru \\
\hline 5 & MTU 1001 & RARS, Maruteru & 38 & PLA-1100 & RARS, Maruteru \\
\hline 6 & MTU 1006 & RARS, Maruteru & 39 & POKKALI & RARS, Maruteru \\
\hline 7 & MTU 1010 & RARS, Maruteru & 40 & SM-1 & RARS, Maruteru \\
\hline 8 & MTU 1031 & RARS, Maruteru & 41 & SM-2 & RARS, Maruteru \\
\hline 9 & MTU 1032 & RARS, Maruteru & 42 & SM-3 & RARS, Maruteru \\
\hline 10 & MTU 1061 & RARS, Maruteru & 43 & SM-4 & RARS, Maruteru \\
\hline 11 & MTU 1064 & RARS, Maruteru & 44 & SM-6 & RARS, Maruteru \\
\hline 12 & MTU 1071 & RARS, Maruteru & 45 & SM-7 & RARS, Maruteru \\
\hline 13 & MTU 1075 & RARS, Maruteru & 46 & SM-8 & RARS, Maruteru \\
\hline 14 & MTU 1078 & RARS, Maruteru & 47 & SM-9 & RARS, Maruteru \\
\hline 15 & MTU 1112 & RARS, Maruteru & 48 & SM-10 & RARS, Maruteru \\
\hline 16 & MTU 1121 & RARS, Maruteru & 49 & SM-11 & RARS, Maruteru \\
\hline 17 & MTU 1140 & RARS, Maruteru & 50 & SM-13 & RARS, Maruteru \\
\hline 18 & MTU 1153 & RARS, Maruteru & 51 & SM-14 & RARS, Maruteru \\
\hline 19 & MTU 1156 & RARS, Maruteru & 52 & SM-15 & RARS, Maruteru \\
\hline 20 & MTU 1166 & RARS, Maruteru & 53 & SM-16 & RARS, Maruteru \\
\hline 21 & MTU 1184 & RARS, Maruteru & 54 & SM-17 & RARS, Maruteru \\
\hline 22 & MTU 1187 & RARS, Maruteru & 55 & SM-18 & RARS, Maruteru \\
\hline 23 & MTU 1194 & RARS, Maruteru & 56 & SM-19 & RARS, Maruteru \\
\hline 24 & MTU 1210 & RARS, Maruteru & 57 & SM-23 & RARS, Maruteru \\
\hline 25 & MTU 1224 & RARS, Maruteru & 58 & SM-24 & RARS, Maruteru \\
\hline 26 & MTU 1226 & RARS, Maruteru & 59 & SM- 25 & RARS, Maruteru \\
\hline 27 & MTU 1229 & RARS, Maruteru & 60 & SM-26 & RARS, Maruteru \\
\hline 28 & MTU 2067 & RARS, Maruteru & 61 & SM-27 & RARS, Maruteru \\
\hline 29 & MTU 2077 & RARS, Maruteru & 62 & SM-28 & RARS, Maruteru \\
\hline 30 & MTU 2716 & RARS, Maruteru & 63 & SM-29 & RARS, Maruteru \\
\hline 31 & MTU 3626 & RARS, Maruteru & 64 & SM-30 & RARS, Maruteru \\
\hline 32 & MTU 4870 & RARS, Maruteru & 65 & SM-31 & RARS, Maruteru \\
\hline 33 & MTU 5182 & RARS, Maruteru & 66 & SM-3-1 & RARS, Maruteru \\
\hline
\end{tabular}


Table. 1 continued

\begin{tabular}{|c|l|l|l|l|l|}
\hline S.No. & Genotype & Source & S.No. & Genotype & Source \\
\hline $\mathbf{6 7}$ & RTCNP 1 & RARS, Maruteru & 88 & RTCNP 31 & RARS, Maruteru \\
\hline $\mathbf{6 8}$ & RTCNP 3 & RARS, Maruteru & 89 & RTCNP 33 & RARS, Maruteru \\
\hline $\mathbf{6 9}$ & RTCNP 4 & RARS, Maruteru & 90 & RTCNP 34 & RARS, Maruteru \\
\hline $\mathbf{7 0}$ & RTCNP 5 & RARS, Maruteru & 91 & RTCNP 35 & RARS, Maruteru \\
\hline $\mathbf{7 1}$ & RTCNP 6 & RARS, Maruteru & 92 & RTCNP 36 & RARS, Maruteru \\
\hline $\mathbf{7 2}$ & RTCNP 7 & RARS, Maruteru & 93 & RTCNP 37 & RARS, Maruteru \\
\hline $\mathbf{7 3}$ & RTCNP 8 & RARS, Maruteru & 94 & RTCNP 38 & RARS, Maruteru \\
\hline $\mathbf{7 4}$ & RTCNP 9 & RARS, Maruteru & 95 & RTCNP 39 & RARS, Maruteru \\
\hline $\mathbf{7 5}$ & RTCNP 10 & RARS, Maruteru & 96 & RTCNP 40 & RARS, Maruteru \\
\hline $\mathbf{7 6}$ & RTCNP 12 & RARS, Maruteru & 97 & RTCNP 41 & RARS, Maruteru \\
\hline $\mathbf{7 7}$ & RTCNP 13 & RARS, Maruteru & 98 & RTCNP 42 & RARS, Maruteru \\
\hline $\mathbf{7 8}$ & RTCNP 14 & RARS, Maruteru & 99 & RTCNP 43 & RARS, Maruteru \\
\hline $\mathbf{7 9}$ & RTCNP 15 & RARS, Maruteru & 100 & RTCNP 44 & RARS, Maruteru \\
\hline $\mathbf{8 0}$ & RTCNP 17 & RARS, Maruteru & 101 & RTCNP 45 & RARS, Maruteru \\
\hline $\mathbf{8 1}$ & RTCNP 18 & RARS, Maruteru & 102 & RTCNP 46 & RARS, Maruteru \\
\hline $\mathbf{8 2}$ & RTCNP 20 & RARS, Maruteru & 103 & RTCNP 47 & RARS, Maruteru \\
\hline $\mathbf{8 3}$ & RTCNP 21 & RARS, Maruteru & 104 & RTCNP 48 & RARS, Maruteru \\
\hline $\mathbf{8 4}$ & RTCNP 22 & RARS, Maruteru & 105 & RTCNP 49 & RARS, Maruteru \\
\hline $\mathbf{8 5}$ & RTCNP 23 & RARS, Maruteru & 106 & RTCNP 50 & RARS, Maruteru \\
\hline $\mathbf{8 6}$ & RTCNP 28 & RARS, Maruteru & 107 & RTCNP 52 & RARS, Maruteru \\
\hline $\mathbf{8 7}$ & RTCNP 29 & RARS, Maruteru & & & \\
\hline & & & & \\
\hline
\end{tabular}


Table.2 Maximum and minimum mean values recorded for 107 rice genotypes with respect to anaerobic germination traits in the screening methods studied

\begin{tabular}{|c|c|c|c|c|c|c|c|}
\hline \multirow[t]{2}{*}{ S.No. } & \multirow[t]{2}{*}{ Character } & \multicolumn{3}{|c|}{ Test tube method } & \multicolumn{3}{|c|}{ Pro-tray method } \\
\hline & & Maximum & Minimum & Mean & Maximum & Minimum & Mean \\
\hline 1 & Germination (\%) & MTU 1140 (99.00) & $\begin{array}{l}\text { MTU } 1156(20.00) \text {, } \\
\text { RTCNP } 23 \text { (20.00) }\end{array}$ & 82.94 & $\begin{array}{c}\text { MTU } 1140 \\
(95.00), \text { RTCNP } \\
50(95.00)\end{array}$ & $\begin{array}{l}\text { MTU 1010, MTU 1156, } \\
\text { BPT 3291, MTU 1187, } \\
\text { NONABOKRA, MTU } \\
\text { 1064, BPT } 3291(25.00)\end{array}$ & 64.96 \\
\hline 2 & Shoot length $(\mathrm{cm})$ & RTCNP 28 (3.62) & SM-3 (1.12) & 2.49 & MTU 1140 (25.65) & SM-10 (9.75) & 16.42 \\
\hline 3 & Root length (cm) & MTU 1032 (4.85) & $\begin{array}{l}\text { MTU 1078, MTU 1166, } \\
\text { MTU 1187, SM-3, SM 3-1, } \\
\text { RTCNP } 14(0.00)\end{array}$ & 1.40 & MTU $1140(6.65)$ & MTU 1010 (0.35) & 4.04 \\
\hline 4 & $\begin{array}{l}\text { Seedling dry } \\
\text { weight (mg) }\end{array}$ & $\begin{array}{c}\text { RTCNP 15, RTCNP } \\
\text { 23, RTCNP 37, } \\
\text { RTCNP } 39(26.00)\end{array}$ & RTCNP 14 (4.00) & 13.60 & MTU 1140 (32.00) & MTU 1010 (13.75) & 21.48 \\
\hline 5 & $\begin{array}{l}\text { Seedling vigour } \\
\text { index }\end{array}$ & MTU 1140 (4.77) & MTU 1010 (0.76) & 2.73 & MTU 1140 (27.00) & MTU 1010 (3.65) & 11.85 \\
\hline 7 & $\begin{array}{l}\text { Anaerobic } \\
\text { response index }\end{array}$ & MTU 1140 (2.28) & $\begin{array}{l}\text { MTU } 1156(0.26) \\
\text { SM-10 }(0.26)\end{array}$ & 1.17 & MTU 1140 (4.85) & MTU 1010 (0.60) & 2.12 \\
\hline
\end{tabular}


Table.3 Tolerant and susceptible genotypes identified for anaerobic germination in the screening methods studied

\begin{tabular}{|c|c|c|c|}
\hline S.No. & Classification & $\begin{array}{l}\text { Number of } \\
\text { genotypes }\end{array}$ & Pro-Tray and Test tube method of screening \\
\hline 1 & Susceptible & 8 & $\begin{array}{l}\text { MTU 1156, MTU 1010, SM-10, SM-14, SM 3-1, SM-7, SM- } \\
\text { 27, NONABOKRA }\end{array}$ \\
\hline 2 & Moderately tolerant & 4 & MTU 1166, MTU 7029, MTU 5293, RTCNP 45 \\
\hline 3 & Tolerant & 31 & $\begin{array}{l}\text { MTU 1031, MTU 1071, POKKALI, SM-4, SM-16, RTCNP } \\
\text { 7, RTCNP 33, RTCNP 34, RTCNP 49, SM-24, SM 30, } \\
\text { RTCNP 4, RTCNP 9, RTCNP 36, RTCNP 40, RTCNP 46, } \\
\text { RTCNP 48, SM-2, SM-23, SM-31, RTCNP 5, RTCNP } \\
\text { 15, RTCNP 21, RTCNP 29, RTCNP 35, RTCNP 37, MTU } \\
\text { 2716, RTCNP 28, PLA-1100, MTU 1140, RTCNP 50. }\end{array}$ \\
\hline
\end{tabular}

Table.4 Promising tolerant genotypes identified for anaerobic germination in the screening methods studied

\begin{tabular}{|c|c|c|c|c|c|c|c|c|c|c|c|c|c|}
\hline \multirow[t]{2}{*}{ S.No. } & \multirow[t]{2}{*}{ Genotypes } & \multicolumn{2}{|c|}{$\begin{array}{c}\text { Germination } \\
(\%)\end{array}$} & \multicolumn{2}{|c|}{ Shoot $\begin{array}{c}\text { length } \\
(\mathrm{cm})\end{array}$} & \multicolumn{2}{|c|}{ Root length(cm) } & \multicolumn{2}{|c|}{$\begin{array}{l}\text { Seedling dry } \\
\text { weight (mg) }\end{array}$} & \multicolumn{2}{|c|}{$\begin{array}{l}\text { Seedling } \\
\text { vigour index }\end{array}$} & \multicolumn{2}{|c|}{$\begin{array}{l}\text { Anaerobic } \\
\text { response index }\end{array}$} \\
\hline & & TT & PT & TT & PT & TT & PT & TT & PT & TT & PT & TT & PT \\
\hline 1 & MTU 1140 & 99.00 & 95.00 & 3.60 & 25.65 & 3.04 & 6.65 & 23.45 & 32.9 & 4.77 & 27.00 & 2.28 & 4.85 \\
\hline 2 & MTU 2716 & 91.00 & 91.00 & 3.17 & 22.85 & 4.16 & 5.25 & 12.70 & 27.70 & 4.00 & 22.69 & 1.28 & 3.85 \\
\hline 3 & SM-2 & 97.00 & 89.00 & 2.79 & 23.35 & 1.18 & 6.20 & 19.00 & 28.40 & 3.29 & 23.74 & 1.68 & 3.55 \\
\hline 4 & RTCNP 28 & 95.00 & 93.00 & 3.62 & 23.75 & 1.29 & 5.85 & 14.5 & 29.55 & 4.06 & 23.97 & 1.62 & 3.90 \\
\hline 5 & RTCNP 29 & 91.00 & 90.00 & 1.98 & 20.25 & 1.55 & 5.60 & 12.5 & 23.55 & 2.46 & 18.64 & 1.13 & 3.05 \\
\hline
\end{tabular}

TT: Test Tube method;

PT: Pro-tray method 


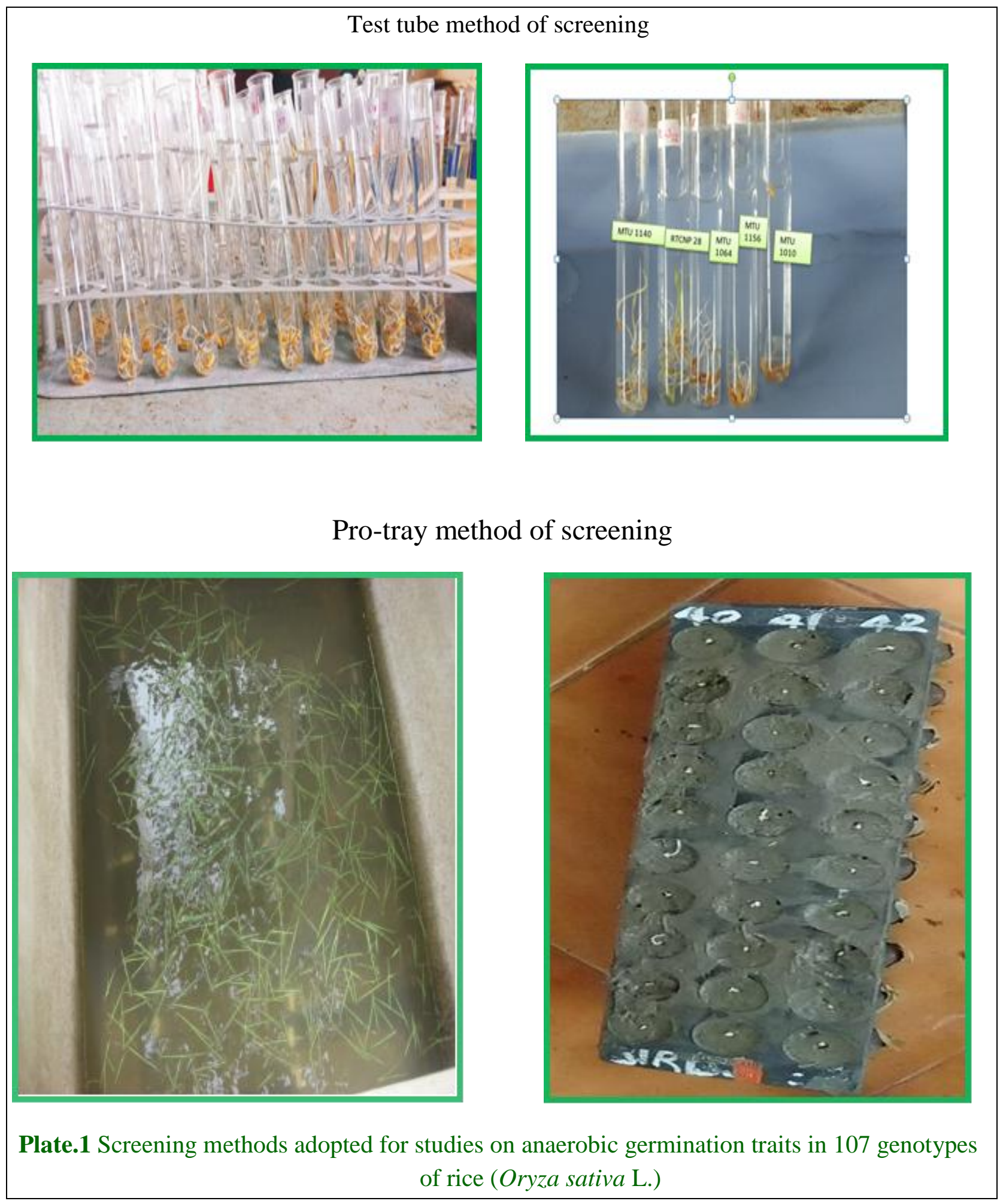



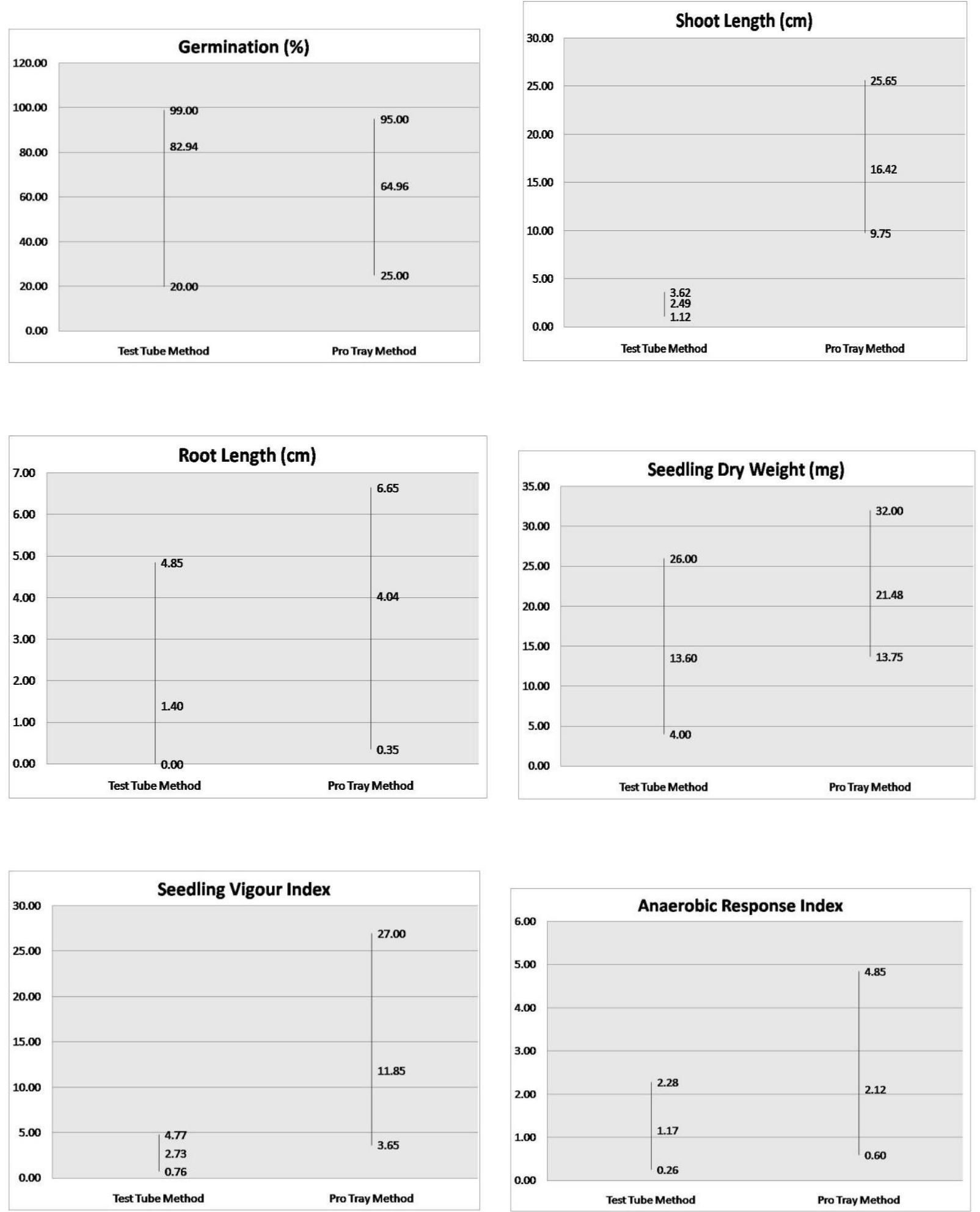

Fig.1 Range for anaerobic germination traits studied in the present investigation for two different screening methods 
The trait anaerobic response index (ARI) is one of the crucial parameter that helps to distinguish between tolerant and susceptible entries. Genotypes with the ability to elongate the shoot rapidly under submerged condition along with high germination percentage exhibit higher anaerobic response index. MTU 1156 (0.26) and SM-10 (0.26) exhibited low anaerobic response index and MTU 1140 (2.28) recorded high anaerobic response index in test tube method. In pro-tray method MTU 1010 (0.60) recorded low ARI and MTU 1140 recorded the highest ARI (4.85). The genotypes which exhibited high germination percentage, shoot length and root length exhibited high anaerobic response index in test tube method (MTU 1121, SM-15 and MTU 1140) and pro-tray method (MTU 2716, MTU 1140, POKKALI, PLA-1100, SM-23, SM-31, RTCNP 14, RTCNP 21, RTCNP 29, RTCNP 36, RTCNP 48 and RTCNP 50). These results are in conformity with Hsu and Tung (2015) and Chaitanya (2016).

In general, test tube method of screening resulted in higher mean germination per cent (82.94\%), compared to pro-tray method of screening $(64.96 \%)$ and was found to be effective in categorization of genotypes as tolerant or susceptible for anaerobic germination. This method is therefore inferred to be useful for evaluating large number of genotypes and rapid identification of genotypes tolerant to anaerobic conditions. Roy and Sharma (2014) also reported test tube method of screening to be more simple and rapid method of bioassay for screening large number of genotypes for anaerobic germination. However, with regard to all other traits, namely shoot length $(16.42 \mathrm{~cm} \mathrm{vs}$ $2.49 \mathrm{~cm})$, root length $(4.04 \mathrm{~cm}$ vs $1.40 \mathrm{~cm})$, seedling dry weight (21.48 mg vs $13.60 \mathrm{mg})$, seedling vigour index (11.85 vs 2.73) and anaerobic response index (2.12 vs 1.17) protray method of screening had recorded higher values compared to test tube method of screening. Hence, pro-tray method of screening is recommended for greater accuracy and reliable results for identification of potential genotypes tolerant to anaerobic conditions and use under direct seeding method of rice cultivation in standing water under puddled condition.

The promising genotypes tolerant to anaerobic conditions and suitable for direct seeding under standing water conditions of puddled soil identified in the present study are presented in Table 4. Among these, MTU 1140 possessing AG gene (Girijarani et al., 2014) and superior germination per cent, shoot length, root length and seedling dry weight in addition to seedling vigour index and anaerobic response index was identified as the most promising genotype for direct seeding under both methods of screening studied. Other tolerant genotypes identified viz., MTU 2716, SM-2, RTCNP 28 and RTCNP 48 also exhibited high values for most of the traits in both the methods of screening. These genotypes need to be analyzed further for innate study of their physiological mechanisms for their tolerance to anaerobic conditions under direct seeded cultivation towards development of diverse cultivars tolerant to anaerobic conditions.

\section{Acknowledgment}

The financial assistance received from University Grants Commission (UGC)-Rajiv Gandhi National Fellowship, Government of India, for the study is gratefully acknowledged.

\section{References}

Barik, J., Kumar, V., Lenka, S.K and Panda, D. 2019. Genetic potentiality of lowland indigenous indica rice (Oryza sativa L.) landraces to anaerobic germination potential. Indian Journal of Plant 
Physiology.1-13.

Bordoloi, D and Sarma. 2018. Aerobic versus anaerobic germination performance of selected rice (Oryza sativa L.) genotypes with or without submergence tolerance. Journal of Experimental Biology and Agricultural Sciences. 6 (6): 947-958.

Chaitanya, S.M. 2016. Variability studies for early vigour, anaerobic germination, yield components in rice (Oryza sativa L.) genotypes. M.Sc (Ag) Thesis. Acharya N.G Ranga Agricultural University, Guntur, India.

Girijarani, M., Satyanarayana, P.V., Suryanarayana, Y., Rao, R.P.V, Neerajakshi, Chamundeswari, N., Ravikumar, B.N.V.S.R, Vishnuvardhan, K.M and Bharathalakshmi, M. 2014. Development of new flood tolerant rice varieties for coastal Andhra Pradesh. Life Sciences International Research Journal. 1 (1): 143-147.

Hsu, S.K and Tung, C.W. 2015.Genetic mapping of anaerobic germinationassociated QTLs controlling coleoptile elongation in rice. Rice. 8 (1): 1-12.

Ismail, A.M., Ella, E.S., Vergara, G.V and Mackill, D.J. 2009. Mechanisms associated with tolerance to flooding during germination and early seedling growth in rice (Oryza sativa). Annals of Botany.103: 197-209.

Joshi, E., Kumar, D., Lal, B., Nepalia, V., Gautam, P and Vyas, A.K. 2013. Management of direct seeded rice for enhanced resource use efficiency. Plant Knowledge Journal. 2 (3): 119-134.

Kharb, R.P.S., Lather, B.P.S., Deswal, D.P. 1994. Prediction of field emergence through heritability and genetic advance of vigour parameters. Seed Science and Technology. 22: 461-466.

Manigbas, N.L., Solis, R.O., Barroga, W.V., Noriel, A.J., Arocena, E.C., Padolina, T.F and Cruz, R.T., 2008. Development of screening methods for anaerobic germination and seedling vigor in direct wet-seeded rice culture. Philippine Journal of Crop Science. 33(3): 34-44.

Miro, B and Ismail, M.A. Tolerance of anaerobic conditions caused by flooding during germination and early growth in rice (Oryza sativa L.). 2013. Frontiers in Plant Science. 4 (269): 1-18.

Pandey S (1995) Socio-economic research issues on wet seeding. In: Constraints, Opportunities, and Innovations for Wet Seeded Rice, IRRI: 73-79.

Pandey S and Velasco L. 2002. Economics of direct seeding in Asia: patterns of adoption and research priorities. p. 3-8. In:. Pandey, S., Mortimer, M., Wade, L., Lopez, K., Hardy, B (Eds.) Direct seeding: research strategies and opportunities. International Rice Research Institute, Los Banos, Philippines.

Rauf, M., Choi, Y.M., Lee, S., Lee, M.C., Sejong, O and Hyun, D.Y. 2019. Evaluation of anaerobic germinability in various rice subpopulations: identifying genotypes suitable for direct seeded rice cultivation. Euphytica. 215:19

Reddy, S.B and Girijarani, M. 2018. Evaluation of Near Isogenic Lines (NILs) of rice for major abiotic stresses of coastal areas. Electronic Journal of Plant Breeding. 9 (3): 808-814.

Roy, S.C and Sharma, B.D. 2014. Assessment of genetic diversity in rice (Oryza sativa L.) germplasm based on agro-morphology traits and zinc-iron content for crop improvement. Physiology and Molecular Biology of Plants. 20 (2): 209-224.

Vijayan, J., Senapati, S., Ray, S., Chakraborty, K., Molla, K. A., Basak, N. (2018). Transcriptomic and physiological studies identify cues for germination stage oxygen deficiency tolerance in rice. Environmental and 
Experimental Botany. 147: 15-248. Yang, J., Li, D.K.S., Luo, L., Liu, Y., Huang, M., Yang, G., Liu, H., Wang, H., Chen, $\mathrm{Z}$ and Guo, T. 2019. Identification of stable QTLs and candidate genes involved in anaerobic germination tolerance in rice via high-density genetic mapping and RNA-Seq. BMC Genomics. 20 (355): 1-15.

\section{How to cite this article:}

Sudeepthi, K., T. Srinivas, B. N. V. S. R. Ravi Kumar, D.P.B. Jyothula and Nafeez Umar, S. K. 2019. Screening for Tolerance to Anaerobic Germination in Rice (Oryza sativa L.). Int.J.Curr.Microbiol.App.Sci. 8(12): 2527-2538. doi: https://doi.org/10.20546/ijcmas.2019.812.296 